\title{
Changes in the metabolism of glucose, pyruvate, glutamine and glycine during maturation of cattle oocytes in vitro
}

\author{
D. Rieger and N. M. Loskutoff* \\ Animal Biotechnology Embryo Laboratory, Department of Biomedical Sciences, University of \\ Guelph, Guelph, Ontario, Canada, N1G 2W1
}

\begin{abstract}
After maturation in vitro for $0,6,12,18$ or $24 \mathrm{~h}$, the metabolism of radiolabelled glucose, glutamine, pyruvate and glycine by individual cattle oocytes was measured for $3 \mathrm{~h}$. The metabolism of glucose through the Embden-Meyerhof (1.77-2.66 pmol per oocyte per $3 \mathrm{~h}$ ) and pentose-phosphate $(0.39-0.75 \mathrm{pmol}$ per oocyte per $3 \mathrm{~h}$ ) pathways was low and did not change over time. The oxidative metabolism of glucose carbon through the Krebs cycle was low throughout maturation, but increased significantly $(P \leqslant 0.05)$ at $6 \mathrm{~h}(0.41 \mathrm{pmol}$ per oocyte per $3 \mathrm{~h})$ and $18 \mathrm{~h}(0.69 \mathrm{pmol}$ per oocyte per $3 \mathrm{~h})$. Pyruvate, glutamine and glycine metabolism in the Krebs cycle increased during culture. Pyruvate metabolism increased significantly from $0 \mathrm{~h}$ ( 17.3 pmol per oocyte per $3 \mathrm{~h})$ to $6 \mathrm{~h}(23.3$ pmol per oocyte per $3 \mathrm{~h}$ ) and reached a maximum at $12 \mathrm{~h}(30.8 \mathrm{pmol}$ per oocyte per $3 \mathrm{~h})$. Glutamine metabolism was unchanged from 0 to $12 \mathrm{~h}(0.89 \mathrm{pmol}$ per oocyte per $3 \mathrm{~h})$, and then increased significantly at $18 \mathrm{~h}(2.25 \mathrm{pmol}$ per oocyte per $3 \mathrm{~h})$. Glycine metabolism increased significantly from $6 \mathrm{~h}$ $(0.21$ pmol per oocyte per $3 \mathrm{~h})$ to $12 \mathrm{~h}(0.46 \mathrm{pmol}$ per oocyte per $3 \mathrm{~h})$ and reached a maximum at $18 \mathrm{~h}(0.68 \mathrm{pmol}$ per oocyte per $3 \mathrm{~h})$. The results suggest that oxidative metabolism increases, and is the major site of cellular energy production, during maturation of the cattle oocyte in vitro.
\end{abstract}

\section{Introduction}

Biggers et al. (1967) showed that pyruvate or oxaloacetate, but not glucose, lactate or phosphoenolpyruvate, can support the maturation of denuded mouse oocytes through meiosis to metaphase II. Denuded oocytes produce significantly greater amounts of ${ }^{14} \mathrm{CO}_{2}$ from $\left[{ }^{14} \mathrm{C}\right]$ pyruvate than from $\left[{ }^{14} \mathrm{C}\right]$ glucose: 57 and 28 times greater in mice and rabbits, respectively, (Brinster, 1969), 15-20 times greater in Rhesus monkeys (Brinster, 1971), and up to 10 times greater in cattle (Khurana and Niemann, 1992). These observations suggest that mitochondrial oxidative metabolism is much more important than anaerobic glucose metabolism for energy production in the mammalian oocyte.

Zuelke and Brackett (1992) cultured cattle cumulus-oocyte complexes for $24 \mathrm{~h}$ and then measured glucose metabolism by the intact complex and by denuded oocytes. Total glucose metabolism was significantly greater by cumulus-oocyte complexes matured in the presence rather than in the absence of LH, but was undetectable in the denuded oocytes. They subsequently showed that glutamine metabolism was greater in intact cumulus-oocyte complexes and in denuded oocytes following maturation in the presence of LH than in its absence

*Present address: Henry Doorly Zoo, 3701 South 10 St., Omaha, NE 68107-2200, USA.

Received 30 April 1993
(Zuelke and Brackett, 1993). Khurana and Niemann (1992) reported that pyruvate metabolism was significantly greater in cattle oocytes denuded after $24 \mathrm{~h}$ maturation in vitro than in immature oocytes. However, with the exception of a preliminary report of some of the results presented here (Rieger and Loskutoff, 1993), there are, to our knowledge, no published studies of the changes in the metabolic activity of cattle oocytes over the course of maturation in vitro.

As in previous studies of early cattle embryos (Rieger and Guay, 1988; Tiffin et al., 1991; Rieger et al., 1992a, b), the production of ${ }^{3} \mathrm{H}_{2} \mathrm{O}$ from $\mathbf{D}-\left[5-{ }^{3} \mathrm{H}\right]$ glucose was used as a measure of glucose metabolism through the Embden-Meyerhof pathway (to phosphoenolpyruvate), and the production of ${ }^{14} \mathrm{CO}_{2}$ from D-[1- $\left.{ }^{14} \mathrm{C}\right]$ glucose and $\mathrm{D}-\left[6-{ }^{14} \mathrm{C}\right]$ glucose was used to determine the relative amounts of glucose metabolized through the pentose-phosphate pathway and the Krebs cycle. The production of ${ }^{14} \mathrm{CO}_{2}$ from $\left[2-{ }^{14} \mathrm{C}\right]$ pyruvate and the production of ${ }^{3} \mathrm{H}_{2} \mathrm{O}$ from $\mathrm{L}-\left[3,4-{ }^{3} \mathrm{H}(\mathrm{N})\right]$ glutamine were used to measure mitochondrial oxidative metabolism. The production of ${ }^{3} \mathrm{H}_{2} \mathrm{O}$ from $\left[2-{ }^{3} \mathrm{H}\right] g l y c i n e$ was measured because glycine is found in high concentrations in bovine follicular fluid (Ménézo and Testart, 1975) and bovine (Moore and Bondioli, 1993) and ovine (Ménézo, 1973) oviductal secretions, and because of the possibility that glycine may serve as a substrate for energy production in the early mouse embryo (Hobbs and Kaye, 1985; Khatchadourian et al., 1991). 


\section{Materials and Methods}

\section{Oocyte preparation}

For each experiment, 200-250 oocytes were recovered from approximately 20 ovaries obtained from an abattoir, as described by $\mathrm{Xu}$ et al. (1992). The ovaries were from mature, Holstein cows, of unknown age and reproductive status. Within $2 \mathrm{~h}$ after slicing the first ovary, cumulus-oocyte complexes with more than three compact layers of granulosa cells were pooled and cultured in groups of 20 at $38^{\circ} \mathrm{C}$ under $5 \% \mathrm{CO}_{2}$ in air in $100 \mu \mathrm{l}$ microdrops of TCM-199 (Earle's salts) medium (Gibco; Grand Island, NY), supplemented with $25 \mathrm{mmol}$ Hepes $1^{-1}$ (Sigma Chemical Co. St Louis, MO), $1 \mathrm{mmol} \mathrm{L}$-glutamine $1^{-1}$ (Sigma), $2.5 \mathrm{mmol}$ sodium pyruvate $\mathrm{l}^{-1}$ (Sigma), $60 \mathrm{U}$ penicillin $\mathrm{ml}^{-1}$ and $60 \mu \mathrm{g}$ streptomycin $\mathrm{ml}^{-1}$ (Gibco), and $10 \%(\mathrm{v} / \mathrm{v})$ steer serum (Cocalico Biologicals, Reamstown, PA). The microdrops were overlaid with $1.0 \mathrm{ml}$ silicone oil, previously sterilized by filtration $(0.22 \mu \mathrm{m})$ and equilibrated with the culture medium.

After $0,6,12,18$ and $24 \mathrm{~h}$ of culture, 25-30 cumulusoocyte complexes were removed from the microdrops and stripped of cumulus cells (denuded) by gentle pipetting through a series of glass micropipettes with decreasing inner diameters $(200-80 \mu \mathrm{m})$. At each time, 10 oocytes were immediately fixed in methanol:acetic acid (3:1) as described by $\mathrm{Xu}$ et al. (1986). The other 15-20 oocytes were passed through four $1 \mathrm{ml}$ washes of metabolic measurement medium, which was the same as the culture medium described above, but without serum. Of these, 8-10 oocytes were subjected to the $3 \mathrm{~h}$ metabolic measurement (see below), while the rest were cultured in the last wash for $3 \mathrm{~h}$ at $38^{\circ} \mathrm{C}$ under $5 \% \mathrm{CO}_{2}$ in air, as controls. The denuded control and measured oocytes were fixed after the $3 \mathrm{~h}$ metabolic measurement (i.e. at 3, 9, 15, 21 and $27 \mathrm{~h}$ ). An additional 5-10 cumulus-oocyte complexes were removed from the culture drops at those times, stripped of cumulus cells and fixed immediately.

Forty-eight hours after fixation, the oocytes were stained with $1 \%$ aceto-orcein and evaluated for meiotic stage exactly as described by $\mathrm{Xu}$ et al. (1986). The oocytes were examined by phase contrast and Nomarski optics at magnification of $\times 250$ to identify the stages of meiosis. The criteria used to define these specific stages were the same as those reported by $\mathrm{Xu}$ et al. (1986), except that germinal vesicle and germinal vesicle breakdown were used in the present study instead of oocyte nucleus stages I and II, respectively. Briefly, the criteria for the stages were as follows - germinal vesicle: there was a distinct nuclear envelope; germinal vesicle breakdown: the nuclear envelope still present but less distinct; diakinesis: the nuclear envelope was no longer visible but the chromatin remained within the area of the nucleus; late diakinesis: the nucleus area had totally disappeared; metaphase I: the chromosomes were maximally condensed; anaphase-telophase I: the chromosomes were under division or segregation; metaphase II: the contracted metaphase chromosomes and the first polar body were both present.

\section{Metabolic measurements}

Except for the medium, the technique used to measure oocyte metabolism was exactly as described for early cattle embryos by Rieger et al. (1992b). All radiolabelled substrates were purchased from New England Nuclear (Mississaugua, Ontario). The mixtures used for each experiment were: Expt 1: $\left[2-{ }^{14} \mathrm{C}\right]$ pyruvate (specific activity $10.4 \mathrm{mCi} \mathrm{mmol}{ }^{-1}$ ) with D-[5- $\left.{ }^{3} \mathrm{H}\right]$ glucose $\left(15.4 \mathrm{Ci} \mathrm{mmol}^{-1}\right)$; Expt 2: D-[1- $\left.{ }^{14} \mathrm{C}\right]$ glucose $\left(55.4 \mathrm{mCi} \mathrm{mmol}^{-1}\right.$ ) with $\mathrm{L}-\left[3,4-{ }^{3} \mathrm{H}(N)\right]$ glutamine $(30.0 \mathrm{Ci}$ $\left.\mathrm{mmol}^{-1}\right)$; and Expt 3: D-[6- $\left.{ }^{14} \mathrm{C}\right]$ glucose $\left(51.8 \mathrm{mCi} \mathrm{mmol}^{-1}\right)$ with $\left[2{ }^{3} \mathrm{H}\right]$ glycine $\left(48.4 \mathrm{Ci} \mathrm{mmol}{ }^{-1}\right)$. Mixtures of one ${ }^{14} \mathrm{C}$-labelled and one ${ }^{3} \mathrm{H}$-labelled substrate were dried under nitrogen and taken up in metabolic measurement medium to give nominal concentrations of $0.05 \mu \mathrm{Ci} \mu \mathrm{l}^{-1}$ of $\left[2-{ }^{14} \mathrm{C}\right]$ pyruvate and $0.25 \mu \mathrm{Ci} \mu \mathrm{I}^{-1}$ for the other labelled substrates. Individual oocytes were taken up in $2 \mu$ lof the final wash of metabolic measurement medium and placed in the cap of a sterile $2.5 \mathrm{ml}$ polypropylene screw-cap microtube together with $2 \mu \mathrm{l}$ of radiolabelled substrate mixture (total culture volume $4 \mu \mathrm{l}$ ). The final substrate concentrations (labelled plus unlabelled) were $6.9 \mathrm{mmol}$ pyruvate $\mathrm{I}^{-1}$ and $5.55 \mathrm{mmol}$ glucose $1^{-1}$ in Expt $1 ; 7.6 \mathrm{mmol}$ glucose $\mathrm{l}^{-1}$ and $1.7 \mathrm{mmol}$ glutamine $1^{-1}$ in Expt 2; and $8.7 \mathrm{mmol}$ glucose $1^{-1}$ and $0.6 \mathrm{mmol}$ glycine $\mathrm{I}^{-1}$ in Expt 3 . The cap was quickly fitted onto the tube, which had been loaded with $1.5 \mathrm{ml}$ of $25 \mathrm{mmol}$ $\mathrm{NaHCO}_{3} 1^{-1}$ equilibrated with a gas mixture of $5 \% \mathrm{O}_{2}$, $5 \% \mathrm{CO}_{2}$ and $90 \% \mathrm{~N}_{2}$. Two or three sham preparations, containing all reagents but no embryo, were included for each mixture of labelled substrates in each measurement period. These served as control for all nonspecific radioactivity due to machine background, chemiluminescence, bacterial contamination and spontaneous breakdown of the labelled substrate. At the end of the $3 \mathrm{~h}$ measurement period, the caps were removed and the bicarbonate was mixed with $15 \mathrm{ml}$ of scintillation fluid and radioactivity was measured for $10 \mathrm{~min}$ in a liquid scintillation counter. The total radioactivity (d.p.m.) of labelled substrate was determined by mixing $2 \mu \mathrm{l}$ of the labelled substrate solution with $1.5 \mathrm{ml}$ of $25 \mathrm{mmol} \mathrm{NaHCO} \mathrm{I}^{-1}$, and measuring radioactivity in the same way. The amount of each substrate metabolized by each embryo was calculated as described by Tiffin et al. (1991). For each labelled substrate, the mean radioactivity (d.p.m.) for the sham preparations was subtracted from the radioactivity for each embryo. The difference was divided by the total radioactivity of labelled substrate added, and multiplied by the total quantity of substrate (labelled plus unlabelled) in $4 \mu \mathrm{l}$ of medium, and by a product recovery correction factor of 1.27 or 1.41 for the ${ }^{3} \mathrm{H}$-labelled and ${ }^{14} \mathrm{C}$-labelled substrates, respectively (Rieger et al., 1992b).

\section{Statistical analysis}

The proportion of oocytes at an identifiable stage after fixation, and the distributions of oocytes across meiotic stages after each measurement period for the immediately fixed, denuded controls and measured oocytes (combined across all experiments) were compared by $\chi^{2}$ analysis. The effect of maturation time on the metabolism of each substrate in each experiment was evaluated by one-way analysis of variance of $\log (y+1)$, where $y=$ the measured metabolism. The logtransformed means were compared by Duncan's multiple-range tests. 
Table 1. Meiotic stage of cattle oocytes matured in vitro and fixed at the indicated culture times

Culture

time $(\mathrm{h})$
Number of identified oocytes
Percentage of oocytes at the meiotic stage of

\begin{tabular}{lllllll}
\hline GV & GVBD & D & LD & MI & ATI & MII
\end{tabular}

\begin{tabular}{|c|c|c|c|c|c|c|c|c|c|}
\hline 0 & Cumulus enclosed & 25 & 52.0 & 48.0 & & & & & \\
\hline 3 & Cumulus enclosed & 19 & & 89.5 & 10.5 & & & & \\
\hline 3 & Denuded controls & 11 & 9.1 & 90.9 & & & & & \\
\hline 3 & Denuded measured & 25 & 32.0 & 52.0 & 16.0 & & & & \\
\hline 6 & Cumulus enclosed & 24 & 4.2 & 50.0 & 45.8 & & & & \\
\hline 9 & Cumulus enclosed & 16 & & & 100.0 & & & & \\
\hline 9 & Denuded controls & 11 & & & 100.0 & & & & \\
\hline 9 & Denuded measured & 26 & & 15.4 & 76.9 & & 7.7 & & \\
\hline 12 & Cumulus enclosed & 26 & & 11.5 & 11.5 & 61.5 & 15.4 & & \\
\hline 15 & Cumulus enclosed & 19 & & & 10.5 & 31.6 & 31.6 & 26.3 & \\
\hline 15 & Denuded controls & 14 & & 7.1 & & 64.3 & 28.6 & & \\
\hline 15 & Denuded measured & 26 & 3.8 & & 7.7 & 80.8 & 7.7 & & \\
\hline 18 & Cumulus enclosed & 24 & & 4.2 & 4.2 & 12.5 & 8.3 & & 70.8 \\
\hline 21 & Cumulus enclosed & 10 & 10.0 & & & 20.0 & & & 70.0 \\
\hline 21 & Denuded controls & 14 & & & & & & 7.1 & 92.9 \\
\hline 21 & Denuded measured & 24 & & & & 8.3 & & 4.2 & 87.5 \\
\hline 24 & Cumulus enclosed & 20 & & & & & 10.0 & & 90.0 \\
\hline 27 & Cumulus enclosed & 10 & & & & & & & 100.0 \\
\hline 27 & Denuded controls & 12 & & & & & & & 100.0 \\
\hline 27 & Denuded measured & 18 & & & & & 11.1 & & 88.9 \\
\hline
\end{tabular}

Cumulus-enclosed oocytes were cultured within the cumulus cells until the time of fixation. Denuded, control oocytes were stripped of cumulus cells and cultured for $3 \mathrm{~h}$ before fixation. Denuded, measured oocytes were stripped of cumulus cells and their metabolism measured for $3 \mathrm{~h}$ before fixation. GV: germinal vesicle; GVBD: germinal vesicle breakdown; D: diakinesis; LD: late diakinesis; MI: metaphase I; ATI: anaphase-telophase I; MII: metaphase Il.

\section{Results}

The cumulus oophorus expanded during in vitro maturation. From $12 \mathrm{~h}$ of culture onwards, the denuding procedure became more difficult because of increasing mucin production by the cumulus cells.

The meiotic stage was identified for 374 of 461 oocytes fixed $(81.1 \%)$ after $0-27 \mathrm{~h}$ of culture (Table 1$)$. The proportion of identified oocytes was not different $(P>0.05)$ among those fixed immediately after removing the cumulus cells $(76.8 \%)$, after the $3 \mathrm{~h}$ metabolic measurement $(85.0 \%)$, or after a $3 \mathrm{~h}$ control culture $(88.7 \%)$. At the beginning of culture, the oocytes were at the germinal vesicle $(52 \%)$ or germinal vesicle breakdown $(48 \%)$ stage. All the cumulus-enclosed oocytes reached the diakinesis stage by $9 \mathrm{~h}, 57.9 \%$ reached metaphase I or anaphase-telophase I by $15 \mathrm{~h}$ and $100 \%$ reached metaphase II by $27 \mathrm{~h}$. There were no significant differences in the distribution across meiotic stage among the cumulus-enclosed, denuded controls, and measured oocytes at 9,21 or $27 \mathrm{~h}$ $(P>0.10)$. However, at $3 \mathrm{~h}$, only $68 \%$ of the measured denuded oocytes reached the germinal vesicle breakdown or diakinesis stage, compared with $90.9 \%$ of the denuded controls, and $100 \%$ of the cumulus-enclosed oocytes $(P \leqslant 0.05)$. At $15 \mathrm{~h}$, only $7.7 \%$ of the measured oocytes had reached the metaphase I stage, compared with $28.6 \%$ of the denuded controls, and $57.9 \%$ for the cumulus-enclosed oocytes $(P \leqslant 0.05)$.

Analysis of variance of the results of Expt I (Table 2) indicated a significant effect of maturation culture time on the metabolism of $\left[2-{ }^{14} \mathrm{C}\right]$ pyruvate $(P \leqslant 0.02)$. The metabolism of $\left[2-{ }^{14} \mathrm{C}\right]$ pyruvate increased significantly from 0 to $6 \mathrm{~h}$ $(P \leqslant 0.05)$ and reached a maximum value at $12 \mathrm{~h}$. The metabolism of $\left[5-{ }^{3} \mathrm{H}\right]$ glucose did not change significantly throughout maturation $(P>0.50)$.

In Expt 2 (Table 3), there was no significant change in the metabolism of $\left[1-{ }^{14} \mathrm{C}\right]$ glucose $(P>0.15)$. There was a very highly significant overall effect of maturation time on the metabolism of $\left[3,4-{ }^{3} \mathrm{H}\right]$ glutamine metabolism $(P \leqslant 0.001)$, which was unchanged from 0 to $12 \mathrm{~h}$, but increased significantly between 12 and $18 \mathrm{~h}$.

There was a very highly significant effect of maturation time on the metabolism of $\left[6-{ }^{14} \mathrm{C}\right]$ glucose $(P \leqslant 0.0002)$ and $\left[2-{ }^{3} \mathrm{H}\right]$ glycine $(P \leqslant 0.0001$, Expt 3 , Table 4$)$. The metabolism of $\left[6{ }^{14} \mathrm{C}\right.$ ]glucose was undetectable at $0 \mathrm{~h}$ of culture, but increased at $6 \mathrm{~h}$, decreased at $12 \mathrm{~h}$, and then reached a maximum value at $18 \mathrm{~h}$ before falling to undetectable values at $24 \mathrm{~h}$. The metabolism of $\left[2-{ }^{3} \mathrm{H}\right] g l y c i n e$ was unchanged from 0 to $6 \mathrm{~h}$, increased at $12 \mathrm{~h}$ to reach a maximum at $18 \mathrm{~h}$, and then decreased at $24 \mathrm{~h}$ of culture.

\section{Discussion}

The proportion of oocytes undergoing germinal vesicle breakdown at $\mathrm{O} h(48 \%)$ was higher in this study than the $25 \%$ previously reported by $\mathrm{Xu}$ et al. (1986). However, the oocytes examined at $0 \mathrm{~h}$, as defined in this study, may have actually been liberated from the follicles for as long as $2 \mathrm{~h}$ before fixation. Mammalian oocytes spontaneously resume meiotic maturation once they are liberated from antral follicles 
Table 2. Metabolism of $\left[2-{ }^{14} \mathrm{C}\right]$ pyruvate and $\left[5-{ }^{3} \mathrm{H}\right] \mathrm{glucose}$ by individual, denuded, cattle oocytes over a $3 \mathrm{~h}$ period beginning at the indicated culture times

\begin{tabular}{lccc}
\hline & & \multicolumn{2}{c}{ Labelled substrate } \\
\cline { 3 - 4 } $\begin{array}{c}\text { Culture } \\
\text { time }(\mathrm{h})\end{array}$ & $\begin{array}{c}\text { Number of } \\
\text { oocytes }\end{array}$ & $\begin{array}{c}{\left[2-{ }^{14} \mathrm{C}\right] \text { pyruvate }} \\
\text { (pmol per oocyte } \\
\text { per } 3 \mathrm{~h})\end{array}$ & $\begin{array}{c}{\left[5-{ }^{3} \mathrm{H}\right] \text { glucose }} \\
\text { (pmol per oocyte } \\
\text { per } 3 \mathrm{~h} \text { ) }\end{array}$ \\
\hline 0 & 10 & $17.3 \pm 3.04^{\mathrm{a}}$ & $2.07 \pm 0.29$ \\
6 & 10 & $23.3 \pm 1.22^{\mathrm{b}}$ & $2.16 \pm 0.54$ \\
12 & 8 & $30.8 \pm 3.76^{\mathrm{b}}$ & $2.00 \pm 0.62$ \\
18 & 9 & $19.4 \pm 1.98^{\mathrm{a}, \mathrm{b}}$ & $1.77 \pm 0.37$ \\
24 & 9 & $22.0 \pm 1.75^{\mathrm{ab}}$ & $2.26 \pm 0.31$ \\
\hline
\end{tabular}

All values are means $\pm \mathrm{SEM}$

${ }^{a, b}$ Within columns, values with different superscripts are significantly different $(P \leqslant 0.05)$

Table 3. Metabolism of $\left[1-{ }^{14} \mathrm{C}\right]$ glucose and $\left[3,4-{ }^{3} \mathrm{H}\right]$ glutamine by individual, denuded, cattle oocytes over a $3 \mathrm{~h}$ period beginning at the indicated culture times

\begin{tabular}{lccc}
\hline & & \multicolumn{2}{c}{ Labelled substrate } \\
\cline { 3 - 4 } $\begin{array}{c}\text { Culture } \\
\text { time }(\mathrm{h})\end{array}$ & $\begin{array}{c}\text { Number of } \\
\text { oocytes }\end{array}$ & $\begin{array}{c}{\left[1-{ }^{14} \mathrm{C}\right] \mathrm{glucose}} \\
(\mathrm{pmol} \text { per oocyte } \\
\text { per } 3 \mathrm{~h})\end{array}$ & $\begin{array}{c}{\left[3,4-{ }^{3} \mathrm{H}\right] \mathrm{glutamine}} \\
\text { (pmol per oocyte } \\
\text { per } 3 \mathrm{~h} \text { ) }\end{array}$ \\
\hline 0 & 8 & $0.74 \pm 0.11$ & $0.72 \pm 0.11^{\mathrm{a}}$ \\
6 & 9 & $0.39 \pm 0.11$ & $1.08 \pm 0.15^{\mathrm{a}}$ \\
12 & 9 & $0.75 \pm 0.24$ & $0.89 \pm 0.16^{\mathrm{a}}$ \\
18 & 10 & $0.40 \pm 0.13$ & $2.25 \pm 0.28^{\mathrm{b}}$ \\
24 & 10 & $0.74 \pm 0.14$ & $2.46 \pm 0.65^{\mathrm{b}}$ \\
\hline
\end{tabular}

All values are means \pm SEM.

${ }^{a, b}$ Within columns, values with different superscripts are significantly different $(P \leqslant 0.05)$.

Table 4. Metabolism of $\left[6-{ }^{14} \mathrm{C}\right] g$ lucose and $\left[2-{ }^{3} \mathrm{H}\right]$ glycine by individual, denuded, cattle oocytes over a $3 \mathrm{~h}$ period beginning at the indicated culture times

\begin{tabular}{lccc}
\hline & & \multicolumn{2}{c}{ Labelled substrate } \\
\cline { 3 - 4 } $\begin{array}{c}\text { Culture } \\
\text { time (h) }\end{array}$ & $\begin{array}{c}\text { Number of } \\
\text { oocytes }\end{array}$ & $\begin{array}{c}{\left[6-{ }^{14} \mathrm{C}\right] \text { glucose }} \\
(\text { pmol per oocyte } \\
\text { per } 3 \mathrm{~h})\end{array}$ & $\begin{array}{c}{\left[2-{ }^{3} \mathrm{H}\right] \text { glycine }} \\
(\text { pmol per oocyte } \\
\text { per } 3 \mathrm{~h})\end{array}$ \\
\hline 0 & 10 & $0 \quad \pm 0^{\mathrm{a}}$ & $0.15 \pm 0.08^{\mathrm{a}}$ \\
6 & 9 & $0.41 \pm 0.12^{\mathrm{b}, \mathrm{c}}$ & $0.21 \pm 0.07^{\mathrm{a}}$ \\
12 & 10 & $0.18 \pm 0.13^{\mathrm{a}, \mathrm{b}}$ & $0.46 \pm 0.09^{\mathrm{b}, \mathrm{c}}$ \\
18 & 9 & $0.69 \pm 0.21^{\mathrm{c}}$ & $0.68 \pm 0.07^{\mathrm{c}}$ \\
24 & 10 & $0 \quad \pm 0^{\mathrm{a}}$ & $0.42 \pm 0.08^{\mathrm{b}}$ \\
\hline
\end{tabular}

All values are means \pm SEM.

a,b.c Within columns, values with different superscripts are significantly different $(P \leqslant 0.05)$.

(Edwards, 1965; Schroeder and Eppig, 1984). The oocytes examined in this study also matured at a faster rate than those reported by $\mathrm{Xu}$ et al. (1986); $71 \%$ versus $25 \%$ of the oocytes reached metaphase II after $18 \mathrm{~h}$ of in vitro culture, respectively. The reasons for these differences are unclear, but may be due to differences in the concentrations of $\mathrm{LH}$ (Dominko and First,
1992) or other factors present in the culture media used for in vitro maturation; the medium $\mathrm{Xu}$ et al. (1986) used contained $20 \%$ fetal calf serum, whereas $10 \%$ steer serum was used in the present study.

A proportion of the oocytes subjected to the metabolic measurement procedure matured during the measurement 
period, at all tested times. The maturation of oocytes fixed at 9,21 and $27 \mathrm{~h}$ did not differ among the measured, denuded controls and cumulus enclosed groups, but maturation was retarded in the measured oocytes fixed at 3 and $15 \mathrm{~h}$. This finding suggests that the cellular processes involved in germinal vesicle breakdown and late diakinesis are especially dependent on the cumulus cells, or are more sensitive to the mildly adverse conditions associated with transfer of the oocytes to the metabolic measurement apparatus. We have previously observed that cattle embryos at the early cleavage stage are more sensitive to the metabolic measurement procedure than are embryos at later stages (Rieger et al., 1992a), possibly owing to the very short-term exposure to ambient temperature (Loskutoff $e$ t al., 1993).

Total glucose metabolism (as measured by the production of ${ }^{3} \mathrm{H}_{2} \mathrm{O}$ from $\left[5-{ }^{3} \mathrm{H}\right]$ glucose) and the production of ${ }^{14} \mathrm{CO}_{2}$ from $\left[1-{ }^{14} \mathrm{C}\right]$ glucose were low and relatively constant throughout maturation. Khurana and Niemann (1992) observed that production of ${ }^{14} \mathrm{CO}_{2}$ from $\left[\mathrm{U}_{-}{ }^{14} \mathrm{C}\right] \mathrm{glucose}$ increased during maturation of cattle oocytes, but never exceeded 1 pmol per embryo per $h$. We observed very similar values for the metabolism of these labelled substrates by two- to eight-cell cattle embryos, which led us to conclude that glucose metabolism is limited at these early stages before the activation of the embryonic genome (Rieger et al., 1992a).

In contrast to the relatively constant metabolism of $\left[1-{ }^{14} \mathrm{C}\right]$ glucose and $\left[5-{ }^{3} \mathrm{H}\right]$ glucose, the production of ${ }^{14} \mathrm{CO}_{2}$ from $\left[6-{ }^{14} \mathrm{C}\right]$ glucose varied markedly during maturation. At 0 and $24 \mathrm{~h}$, there was no measurable production of ${ }^{14} \mathrm{CO}_{2}$ from $\left[6-{ }^{14} \mathrm{C}\right]$ glucose and, therefore, the production of ${ }^{14} \mathrm{CO}_{2}$ from $\left[1{ }^{14} \mathrm{C}\right.$ glucose $(0.74 \mathrm{pmol}$ per oocyte per $3 \mathrm{~h})$ can be considered to have arisen exclusively from processing through the pentose-phosphate pathway (see Larrabee, 1989). It is unclear why glucose is metabolized through the Embden-Meyerhof pathway as far as phosphoenolpyruvate, but glucose carbon is not metabolized through the Krebs cycle. This might result from inhibition of pyruvate kinase, as we have suggested occurs in cattle blastocysts (Rieger and Guay, 1988), or that glucose is converted to lactate and secreted from the oocyte, as has been observed in early cleavage-stage rat and human embryos (see Leese et al., 1993).

The significant increases in production of ${ }^{14} \mathrm{CO}_{2}$ from $\left[6-{ }^{14} \mathrm{Clglucose}\right.$ at 6 and $18 \mathrm{~h}$, when there were no corresponding increases in production of ${ }^{14} \mathrm{CO}_{2}$ from $\left[1-{ }^{14} \mathrm{Clglucose}\right.$, suggest that the production of ${ }^{14} \mathrm{CO}_{2}$ from $\left[6-{ }^{14} \mathrm{C}\right] g$ lucose at those times arose from oxidative metabolism in the Krebs cycle. At $18 \mathrm{~h}$, this apparent mitochondrial metabolism represented $39 \%$ of total glucose metabolism.

Increasing oxidative metabolism is also indicated by the significant increases in the metabolism of $\left[2{ }^{14} \mathrm{C}\right]$ pyruvate and $\left[3,4-{ }^{3} \mathrm{H}\right]$ glutamine during maturation, reaching their maxima at 12 and 18-24 h, respectively. Khurana and Niemann (1992) also observed a significant increase in the metabolism of $\left[2-{ }^{14} \mathrm{C}\right]$ pyruvate following maturation in vitro, although their measurements were lower by a factor of ten. The maximum metabolism of pyruvate by cattle oocytes in the present study was four times greater, and that of glutamine, three times less, than our previous measurements in two-cell cattle embryos (Rieger et al., 1992a, b). However, it is unclear whether these differences reflect metabolic changes between the oocyte and two-cell stage, or are due to differences in the media used for the metabolic measurements.

The results suggest that glycine can also serve as an energy substrate for cattle oocytes. The production of ${ }^{3} \mathrm{H}_{2} \mathrm{O}$ from $\left[2-{ }^{3} \mathrm{H}\right]$ glycine involves the formation of serine and then pyruvate as intermediates (Voet and Voet, 1990). It is, therefore, not surprising that the pattern of change in glycine metabolism during maturation was similar to that of pyruvate, increasing from $\mathrm{Oh}$ to a maximum at $18 \mathrm{~h}$.

The patterns of metabolic activity during maturation of cattle oocytes in the present study are consistent with changes in the enzyme activities of rat oocytes during maturation in vivo, as reported by Tsutsumi et al. (1992). In their study, the activities of hexokinase and phosphofructokinase, enzymes of the Embden-Meyerhof pathway, increased during maturation while the activities of glucose-6-phosphate dehydrogenase and 6-phosphogluconate dehydrogenase, enzymes of the pentosephosphate pathway, decreased. However, the limited metabolism of $\left[5-{ }^{3} \mathrm{H}\right]$ glucose and $\left[1-{ }^{14} \mathrm{C}\right]$ glucose by cattle oocytes in the present study is consistent with the observation that hexokinase activity is very low throughout maturation of rat oocytes (Tsutsumi et al., 1992), and, therefore, rate-limiting for both the Embden-Meyerhof and pentose-phosphate pathways. The increases in the metabolism of $\left[2-{ }^{14} \mathrm{C}\right]$ pyruvate, $\left[3,4-{ }^{3} \mathrm{H}\right]$ glutamine, $\left[6-{ }^{14} \mathrm{C}\right] g$ lucose, and $\left[2-{ }^{3} \mathrm{H}\right] g l y c i n e$ by cattle oocytes are consistent with the observations that the activity of malate dehydrogenase, an enzyme of the Krebs cycle, doubles (Tsutsumi et al, 1992), and oxygen consumption increases (Magnusson et al, 1977), during maturation of rat oocytes.

The changes in oxidative metabolism may also be related to ultrastructural changes of cattle oocytes during maturation in vitro. Hyttel et al. (1986) and Shamsuddin et al. (1993) reported that mitochondria move from the periphery of cattle oocytes, to become distributed throughout the ooplasm between 12 and $20 \mathrm{~h}$ of maturation in vitro, approximately coincident with the increases in the metabolism of Krebs cycle substrates in the present study. However, further investigation will be necessary to determine whether there is a direct physiological relationship between these observations.

In the present study, the metabolic activity of cattle oocytes was measured after removal of the cumulus cells. These conditions are quite different from the natural situation of metabolic coupling in which glycolytic intermediates, amino acids, ATP and other small molecules produced by the cumulus cells may be secreted and taken up by the oocyte, or transferred into the oocyte through gap junctions (see Eppig, 1991). Pyruvate or oxaloacetate alone can support the maturation of denuded mouse oocytes, but glucose can do so only when follicular cells are present in the culture medium (Biggers et al., 1967). This finding suggests that the cumulus cells metabolize glucose to pyruvate or Krebs cycle intermediates which are passed to the oocyte. To our knowledge, the concentrations of energy substrates to which the cumulus-enclosed oocyte is exposed are completely unknown and may be very different from the concentrations in the medium in this study. Consequently, the measurements of metabolism by denuded cattle oocytes, like all other studies of denuded oocytes, may not necessarily correspond to the absolute activities of the relevant metabolic pathways in 
cumulus-enclosed oocytes. However, these measurements do provide an indication of the potential of the oocyte to metabolize the tested substrates, and the patterns of change in their metabolism probably reflect similar changes in the cumulus-enclosed oocyte.

Financial support was provided by the Natural Sciences and Engineering Research Council of Canada, the Ontario Ministry of Agriculture and Food, the Premier's Council Technology Fund of Ontario, and Semex Canada. The authors thank L. Afflu, N. Rumph and E. Semple for collection and preparation of the oocytes, and J. W. Pollard for his critique of the manuscript.

\section{References}

Biggers JD, Whittingham DG and Donahue RP (1967) The pattern of energy metabolism in the mouse oocyte and zygote Proceedings of the National Academy of Science 58 560-567

Brinster RL (1969) Radioactive carbon dioxide production from pyruvate and lactate by the preimplantation rabbit embryo Experimental Cell Research $\mathbf{5 4}$ 205-209

Brinster RL (1971) Oxidation of pyruvate and glucose by oocytes of the mouse and rhesus monkey Journal of Reproduction and Fertility 24 187-191

Dominko T and First NL (1992) Kinetics of bovine oocyte maturation allows selection for developmental competence and is affected by gonadotropins Theriogenology 37203 (Abstract)

Edwards RG (1965) Maturation in vitro of mouse, sheep, cow, pig, rhesus monkey and human ovarian oocytes Nature 208 349-351

Eppig لJ (1991) Intercommunication between mammalian oocytes and companion somatic cells Bioessays 13 569-574

Hobbs JG and Kaye PL (1985) Glycine transport in mouse eggs and preimplantation embryos Journal of Reproduction and Fertility 74 77-86

Hyttel P, Xu KP, Smith S and Greve T (1986) Ultrastructure of in-vitro oocyte maturation in cattle Journal of Reproduction and Fertility 78 615-625

Khatchadourian C, Guillaud J and Ménézo Y (1991) Importance of glycine for the mouse one cell zygote and blastocyst metabolism: conversion and absence of a glycine methyl transferase activity Experimental and Clinical Endocrinology 10 45-51

Khurana NK and Niemann H (1992) Energy metabolism of bovine oocytes matured and fertilized in vitro Proceedings of the 12th International Congress on Animal Reproduction, The Hague, Vol. 1, 348-350 (Abstract)

Larrabee M (1989) The pentose cycle (hexose monophosphate shunt). Rigorous evaluation of limits to the flux from glucose using ${ }^{14} \mathrm{CO}_{2}$ data, with applications to peripheral ganglia of chicken embryos Journal of Biological Chemistry 264 15875-15879

Leese HJ, Conaghan J, Martin KL and Hardy K (1993) Early human embryo metabolism Bioessays 15, 259-264

Loskutoff NM, Johnson WH and Betteridge KJ (1993) The developmental competence of bovine embryos with reduced cell numbers Theriogenology 39 $95-107$
Magnusson C, Hillensjo T, Tsafriri A, Hultborn R and Ahren K (1977) Oxygen consumption of maturing rat oocytes Biology of Reproduction 17 9-15

Ménézo YJR (1973) Amino constituents of tubal and uterine fluids of the estrous ewe: comparison with blood serum and ram seminal fluid. In The Biology of Spermatozoa, pp 174-181 Eds ESE Hafez and CG Thibault. S. Karger AG Basel

Ménézo Y and Testart J (1975) Etude comparée du sérum sanquin et du liquide folliculaire préovulatoire chez la vache Annales de Biologie Animale, Biochimie, Biophysique 15 1-8

Moore K and Bondioli KR (1993) Glycine and alanine supplementation of culture medium enhances development of in vitro matured and fertilized cattle embryos Biology of Reproduction 48 833-840

Rieger D and Guay P (1988) Measurement of the metabolism of energy substrates in individual bovine blastocysts joumal of Reproduction and Fertility 83 585-591

Rieger D and Loskutoff NM (1993) Changes in the metabolism of glucose, pyruvate and glutamine during in-vitro maturation of bovine oocytes Theriogenology 39298 (Abstract)

Rieger D, Loskutoff NM and Betteridge KJ (1992a) Developmentally related changes in the metabolism of glucose and glutamine by cattle embryos produced and co-cultured in vitro Joumal of Reproduction and Fertility 95 585-595

Rieger D, Loskutoff NM and Betteridge KJ (1992b) Developmentally related changes in the uptake and metabolism of glucose, glutamine and pyruvate by cattle embryos produced in vitro Reproduction Fertility and Development 4 $547-557$

Schroeder AC and Eppig JJ (1984) The developmental capacity of mouse oocytes that matured spontaneously in vitro is normal Developmental Biology $102493-497$

Shamsuddin M, Larsson B and Rodriguez-Martinez H (1993) Maturation-related changes in bovine oocytes under different culture conditions Animal Reproduction Science $3149-60$

Tiffin G, Rieger D, Betteridge KJ, Yadav BR and King WA (1991) Glucose and glutamine metabolism in pre-attachment cattle embryos in relation to sex and stage of development Journal of Reproduction and Fertility 93 125-132

Tsutsumi O, Satoh K, Taketani Y and Kato T (1992) Determination of enzyme activities of energy metabolism in the maturing rat oocyte Molecular Reproduction and Development 33 333-337

Voet D and Voet JG (1990) Biochemistry, p 1223. John Wiley and Sons, Inc., New York

Xu KP, Greve T, Smith S and Hyttel P (1986) Chronological changes of bovine follicular oocyte maturation in vitro Acta veterinaria Scandinavica 27, 505-519

Xu KP, Yadav BR, Rorie RW, Plante L, Betteridge KJ and King WA (1992) Development and viability of bovine embryos derived from oocytes matured and fertilized in vitro and co-cultured with bovine oviducal epithelial cells Journal of Reproduction and Fertility 94 33-43

Zuelke KA and Brackett BG (1992) Effects of luteinizing hormone on glucose metabolism in cumulus-enclosed bovine oocytes matured in vitro Endocrinology $1312690-2696$

Zuelke KA and Brackett BG (1993) Increased glutamine metabolism in bovine cumulus-cell enclosed and denuded oocytes after in vitro maturation with luteinizing hormone Biology of Reproduction 48 815-820 